\title{
A sensitivity study of fast outlet glaciers to short timescale cyclical perturbations
}

\section{E. Aykutlug and T. K. Dupont}

Department of Earth System Science, University of California Irvine, 3200 Croul Hall, Irvine, CA 92697-3100, USA

Received: 9 December 2014 - Accepted: 15 December 2014 - Published: 12 January 2015

Correspondence to: E. Aykutlug (eaykutlu@uci.edu)

Published by Copernicus Publications on behalf of the European Geosciences Union.

A sensitivity study of fast outlet glaciers

E. Aykutlug and

T. K. Dupont

Title Page

14

4

Back

Full Screen / Esc

Printer-friendly Version 


\section{Abstract}

The dynamic response of outlet glaciers on short (annual to decadal) timescales is affected by various external forcings, such as basal or oceanic conditions. Understanding the sensitivity of the dynamic response to such forcings can help assess more accu-

5 rate ice volume projections. In this work, we investigate the spatiotemporal sensitivity of outlet glaciers to fast cyclical forcings using a one-dimensional depth and widthaveraged heuristic model. Our results indicate that even on such short timescales, nonlinearities in ice dynamics may lead to an asymmetric response, despite the forcing functions being symmetric around each reference value. Results also show that 10 such short-timescale effects become more pronounced as glaciers become closer to flotation. While being qualitatively similar for both downsloping and upsloping bed geometries, the results indicate higher sensitivity for upsloping ("West Antarctica-like") beds. The range in asymmetric response for different configurations motivate parameterizing or including short-timescale effects in models while investigating the dynamic 15 behavior of outlet glaciers.

\section{Introduction}

Outlet glaciers and ice streams play an important role in sea-level changes by controlling a significant amount of ice flux from the Antarctic and Greenland ice sheets (e.g., Bamber et al., 2000; Rignot et al., 2011; Moon et al., 2012; Enderlin et al., 2014). Recent observations show that outlet glaciers can respond to external forcings on short (annual to decadal) timescales that can be driven by different environmental changes, e.g., in basal conditions, oceanic forcing, climate variations or ice-front position (Zwally et al., 2002; Holland et al., 2008; Howat et al., 2008, 2010; Amundson et al., 2010; Podrasky et al., 2012; Joughin et al., 2012, 2014).

25 On the other hand, it is often hard to identify the individual contribution of each process to these changes (e.g., Joughin et al., 2012), because the feedback mechanisms

\section{A sensitivity study of fast outlet glaciers \\ E. Aykutlug and \\ T. K. Dupont}

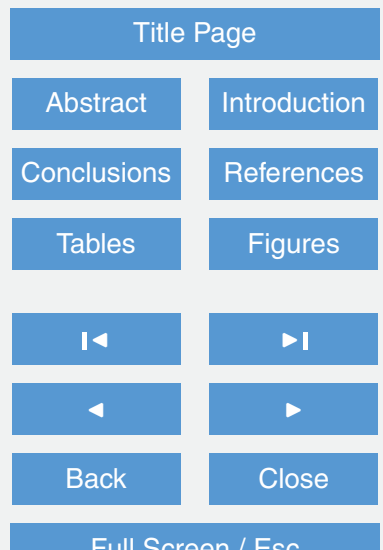

Full Screen / Esc

Printer-friendly Version

Interactive Discussion 
within ice dynamics can lead to complicated response (e.g., Schoof, 2010; Hoffman et al., 2011). Several studies show that including external forcings on short timescales can have prominent effect on modeling the dynamics of certain outlet glaciers (Howat et al., 2010; Vieli and Nick, 2011; Joughin et al., 2012; Nick et al., 2013; Gladstone 5 et al., 2014; Habermann et al., 2013; Enderlin et al., 2013a, b). Therefore, understanding the sensitivity of outlet glaciers to external forcing on these timescales can improve ice-volume projections, and their contribution to sea-level changes.

The main objective of this work is to investigate whether explicitly including shorttimescale variations in certain model parameters, rather than simply applying fixed 10 time-averaged values, will yield significantly different fast outlet-glacier behavior. Rather than the cause and effect of specific processes, we are interested in analyzing the sensitivity to changes in certain parameters that can be directly or indirectly caused by different processes. To this end, we simplify the problem by only considering variations in basal friction, ice hardness, accumulation rate, and sub-shelf melting.

15 The basal friction coefficient is considered to be representative of all the basal changes on the grounded ice that are thought to modify the basal resistance. Changes in thermo-mechanical properties of the ice are considered through variations in ice hardness. Net accumulation rate, which is the difference between the accumulation and ablation rates, represents the net surface mass balance. Finally, changes in oceanic forcing is considered by applying sub-shelf melting.

The timescale of these forcings can vary from sub-annual to decadal (e.g., Howat et al., 2008), therefore we apply perturbations on both annual and decadal timescales. We also consider cases where perturbations are applied both individually and in combination, because multiple perturbations are likely to affect ice dynamics simultaneously.

The effects of cyclical perturbations are analyzed by mainly focusing on the dynamics of the grounding line. Grounding-line (GL) migration has received considerable attention, because it plays a key role in the stability and long-term behavior of ice sheets, specifically as a fundamental component of marine ice sheet instability (e.g., Weertman, 1974; Hindmarsh, 1996; Schoof, 2007, 2012). Numerous studies have analyzed
TCD

9, 223-250, 2015

A sensitivity study of fast outlet glaciers

E. Aykutlug and

T. K. Dupont

Title Page

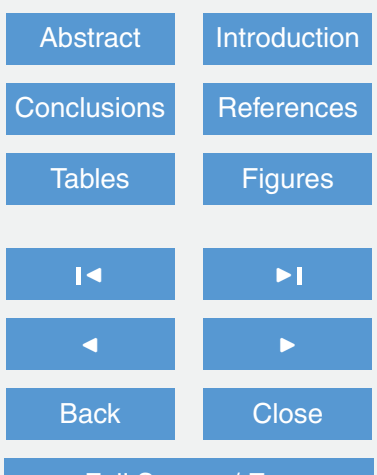

Full Screen / Esc

Printer-friendly Version

Interactive Discussion 
the sensitivity of GL dynamics to various external forcings, e.g., buttressing (Dupont and Alley 2005), sedimentation (Alley et al., 2007), oceanic warming (Walker et al., 2008), orbital-scale climate cycling (Parizek et al., 2010), pinning points (Favier et al., 2012), viscosity (Pattyn et al., 2012), basal friction (Pattyn et al., 2013) and tidal flexure 5 (Christianson et al., 2013).

We investigate whether ice dynamics exhibit asymmetries under advance and retreat which can lead to a bias in GL migration, similar to the longer timescale behavior shown by Parizek et al. (2010). We compare the time-averaged GL positions under cyclical forcings to the reference configurations where the same parameter is kept constant 10 at the average value. We also analyze the change in volume above flotation which is closely related to GL position, but directly affects the sea level.

Ice streams can have complicated bedrock geometries with downsloping and upsloping regions (e.g., Morlighem et al., 2014). Our purpose is not to model a specific region, but to understand the effects of cyclical perturbations on systems with these 15 fundamentally different bedrock geometries, therefore we consider both downsloping and upsloping bedrock geometries. Schoof (2007) has shown that in the absence of lateral drag and lateral variations, marine ice sheets should have only discrete equilibrium points on downsloping beds, and no stable equilibrium points on upsloping beds. Numerical experiments by various models also confirmed this result in Marine Ice Sheet Model Intercomparison (MISMIP) experiments (Pattyn et al., 2012). On the other hand, when lateral drag (Dupont and Alley, 2005; Goldberg et al., 2009) or lateral variations (Gudmundsson, 2013; Gudmundsson et al., 2012) are included, stable configurations can be obtained. In this work we use a width-averaged parameterization of lateral drag that would be present in a plan view or higher dimensional model (Dupont, 2004). For both downsloping and upsloping cases, we choose our reference parameter values to yield a steady-state, and then focus on the sensitivity of the GL positions to cyclical perturbations around these reference configurations.

\section{A sensitivity study of fast outlet glaciers \\ E. Aykutlug and \\ T. K. Dupont}

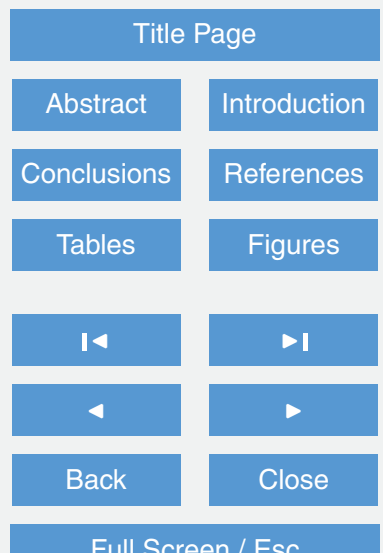

Full Screen / Esc

Printer-friendly Version

Interactive Discussion 


\section{Model description}

\subsection{Stress and mass balance equations}

The fast-flowing outlet glacier dynamics are modeled using a one-dimensional widthaveraged version of the depth-integrated shallow-shelf stress-equilibrium equations

5 (MacAyeal, 1989; Morland, 1987), which are appropriate for sliding-dominant motion, and given by

$\partial_{x}\left(4 h v \partial_{x} u\right)=\tau_{\mathrm{b}}+\tau_{\mathrm{s}}+\rho_{i} g h \partial_{x} z_{\mathrm{s}}$

In Eq. (1) $u$ is the velocity in the $x$-direction, $h$ is the ice-thickness, and $z_{\mathrm{s}}$ is the surface elevation. Viscosity is given by

$v=\frac{B}{2}\left|\partial_{x} u\right|^{\frac{1-n}{n}}$

where $B$ is the depth-averaged ice hardness parameter which is related to ice softness by $B=A^{-\frac{1}{n}}$, and where the Glen's flow-law exponent is set to the commonly adopted value of $n=3$ (Cuffey and Paterson, 2010). A nonlinear basal drag is adopted on the grounded part of the ice sheet, (e.g., Pattyn et al., 2012),

${ }_{15} \tau_{\mathrm{b}}=C_{\mathrm{b}} u^{1 / m}$, where $m=3$.

The lateral drag, is parameterized by half-width, $W$, and the lateral drag coefficient $C_{\mathrm{s}}$, (e.g., Dupont, 2004), such that

$\tau_{\mathrm{s}}=\frac{h}{W} C_{\mathrm{s}} u^{1 / n}$

9, 223-250, 2015

A sensitivity study of fast outlet glaciers

E. Aykutlug and

T. K. Dupont

Title Page

Abstract

Introduction

Conclusions

References

Tables

Figures

14

4

Back

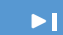



Close

Full Screen / Esc

Printer-friendly Version

The mass balance is given by

$20 \partial_{t} h=-\partial_{x}(u h)+\dot{a}+\dot{b}$ 
where $\dot{a}$ is the net surface mass balance, which is the difference between the accumulation and ablation rates, and $\dot{b}$ represents the sub-shelf melt rate.

At the upstream boundary, $x=0$, a fixed amount of flux is defined at all times $q(0, t)=q_{0}$. The ice thickness and velocity are allowed to vary accordingly. The stress5 equilibrium equations are solved at each time instant using the Dirichlet boundary condition at the upstream boundary, $u_{0}=q_{0} / h(0, t)$, where $h(x, t)$ represents the current ice thickness at a point $x$ and time $t$. At the downstream end, $x=L$, longitudinal stress balance is prescribed by the depth-integrated ice-ocean pressure imbalance

$4 h v \partial_{x} u=\frac{\rho_{i} g}{2}\left(1-\frac{\rho_{i}}{\rho_{\mathrm{w}}}\right) h^{2}, \quad x=L$

10 The ice front position is fixed at $x=L$ at all times, thereby neglecting variations in icefront positions which have been observed to markedly affect the ice dynamics (e.g., Vieli and Nick, 2011; Podrasky et al., 2012; Joughin et al., 2012).

Reference numerical values and description of parameters used in the experiments are given in Table 1. Steady-state configurations corresponding to these values are 15 shown in Fig. 1. A finite-element model is implemented to solve the stress-equilibrium and mass-balance equations using linear basis functions. GL position is determined within a partially-grounded element using a linear interpolation of the hydrostaticbalance equation for flotation. Basal friction is applied on the grounded portion, and sub-shelf melting is applied on the floating portion of the partially-grounded element. 20 In all the experiments a fixed time step is used that is smaller than CFL condition and allows stable integration of dynamics.

Although the sub-elemental parameterization of the GL improves the numerical performance (Seroussi et al., 2014), numerous studies show that numerical difficulties may still arise in implementing GL dynamics using a fixed grid (e.g., Vieli and Payne, 25 2005; Durand et al., 2009; Goldberg et al., 2009; Gladstone et al., 2010; Docquier et al., 2011; Pattyn et al., 2012, 2013). To minimize the effects of such numerical issues, we use uniformly-fine finite elements of length $0.25 \mathrm{~km}$. To illustrate that the $\mathrm{GL}$

A sensitivity study of fast outlet glaciers

E. Aykutlug and

T. K. Dupont

Title Page

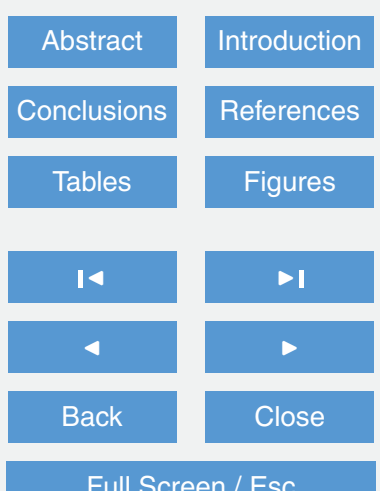

Full Screen / Esc

Printer-friendly Version

Interactive Discussion 
behavior is robust to perturbations for the reference values chosen in this study, we perturb the ice thickness $\pm 50 \mathrm{~m}$ from the reference steady-state positions, and let the system approach steady state from less and more grounded positions. As shown in Fig. 1, for both downsloping and upsloping geometries, the model is able to converge 5 to the same GL positions within an accuracy of less than $10^{-3} \mathrm{~km}$. (Please, also see Sect. 2.2 for further comments on the selection of reference parameters.).

In this preliminary work, we only consider spatially-uniform perturbations on selected parameters, neglecting spatially-varying transient forcing, (e.g., Enderlin et al., 2013b). We also hold the ice-front position fixed, thereby neglecting variations in ice-front po10 sitions which have been observed to markedly affect the ice dynamics (e.g., Podrasky et al., 2012; Joughin et al., 2012; Vieli and Nick, 2011). We leave an analysis which includes such perturbations for future work.

\subsection{Cyclical perturbations}

In this section we explain the details on how the perturbations in basal friction coef15 ficient $\left(C_{\mathrm{b}}\right)$, ice hardness $(B)$, net accumulation rate $(\dot{a})$ and sub-shelf melting $(\dot{b})$ are applied. Although perturbations can be of various shapes, amplitudes and sizes, to simplify the analysis we implement cyclical perturbations as a sinusoidal forcing function, for which the variations average out to zero around the mean. Each parameter under consideration, $C_{\mathrm{b}}, B, \dot{a}$, and $\dot{b}$, experiences a periodic perturbation around its reference value by use of a sinusoidal function of the form

$p(t)=p^{0}+\alpha \frac{p_{\max }-p_{\min }}{2} \sin \frac{2 \pi}{T} t$

where $p^{0}, p_{\min }, p_{\max }$, and $p(t)$ represents the reference, minimum, maximum and the current value of the parameter $p$ respectively. The period, $T$, is set to either $T=1$ or $T=10$ years. The coefficient $\alpha$ is 1.57 so that the average effect of the sinusoidal

magnitude $\left(p_{\max }-p_{\min }\right) / 2$ over the same period, as shown in Fig. $2 a$. In the remainder
TCD

9, 223-250, 2015

A sensitivity study of fast outlet glaciers

E. Aykutlug and

T. K. Dupont

Title Page

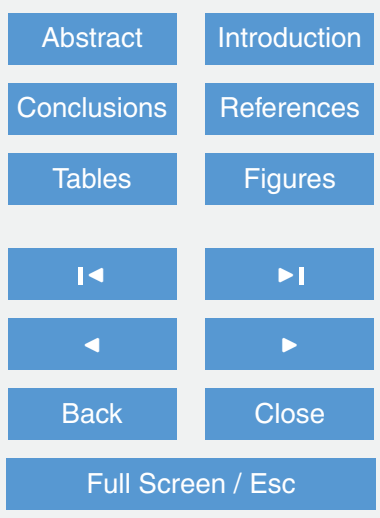

Printer-friendly Version

Interactive Discussion 
of this paper, when we refer to a percentage cyclical perturbation, we would be referring to the average effect of that perturbation over a half period.

The magnitude of perturbation applied is selected differently on each parameter. Various studies show that seasonal velocity changes in ice streams in Greenland can 5 range from $5 \%$ over the inland ice up to $20-40 \%$ near the ice front (e.g., Hoffman et al., 2011; Joughin et al., 2012). In some cases higher changes can be observed (e.g. Joughin et al., 2014). We have chosen to apply a $\pm 10 \%$ annual perturbation of the basal friction coefficient, which leads to approximately $56 \%$ and $36 \%$ variations of the ice-front velocity for the the downsloping and upsloping geometries respectively on 10 annual timescale. When same amount of perturbation is applied on decadal timescale, the ice-front velocity changes are $48 \%$ and $28 \%$ respectively (Fig. 3). Applying the same amount of perturbation on $C_{\mathrm{b}}$ everywhere on the domain is likely to produce variations on surface velocity larger than expected for the inland ice. Taking these two considerations into account, the results on these perturbations could be taken as upper 15 bounds. Future work should address spatially non-uniform variations such that perturbations vary from downstream to upstream.

We consider depth-averaged variations in $B$ only due to changes in surface temperature. In a three-dimensional model or a two-dimensional flow-line model, these changes would be restricted to the layer near the surface. Because, we use a depthaveraged model, this effect is (integrated) averaged in the vertical direction.Variations of the surface temperature decrease exponentially with the depth in ice, (e.g., Eq. (9.8) in Cuffey and Paterson, 2010). The seasonal temperature variations are around 20$40^{\circ} \mathrm{C}$ in Antarctica and Greenland (e.g., Wexler, 1959; Comiso, 2000; Hall et al., 2013). We use the solution to a simple heat diffusion problem for a $1000 \mathrm{~m}$ thick slab of ice to find the depth-integrated average effect of $\pm 10^{\circ}$ temperature variation on ice hardness. Such a variation can be shown to lead to a roughly $0.15 \%$ depth-averaged change in $B$ for a period of one year, and approximately $0.4 \%$ change in $B$ for a period of 10 years. Motivated by this fact, we apply \pm 0.15 and $\pm 0.4 \%$ perturbation on $B$ on annual and decadal timescales respectively.

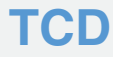

9, 223-250, 2015
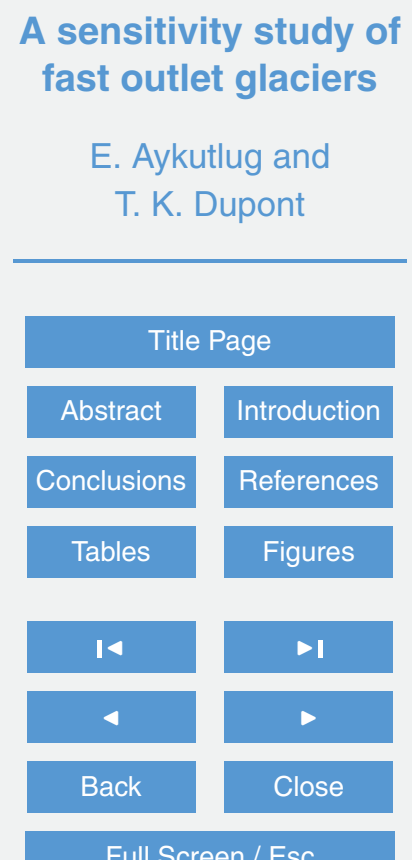

Full Screen / Esc

Printer-friendly Version

Interactive Discussion 
The perturbations on accumulation rate is expected to vary significantly on short timescales. Therefore, we apply $\pm 50 \%$ perturbation on the net accumulation rate. Finally, changes in sub-shelf melting has shown to affect ice dynamics significantly (e.g., Dutrieux et al., 2014; Rignot et al., 2010). We use a relatively modest melt rate of $5-1 \mathrm{myr}^{-1}$ (Rignot et al., 2013; Walker et al., 2008) and consider $\pm 50 \%$ perturbation around this reference value. We chose this melt rate to insure that the $\mathrm{GL}$ is robust to perturbations and do not suffer from numerical issues from using a fixed grid, as illustrated in Fig. 1. For example, when a reference configuration with a melt rate of $-2 \mathrm{~m} \mathrm{yr}^{-1}$ for the upsloping geometry in Fig. $1 \mathrm{~b}$, the difference in GL positions that are 10 reached from more and less grounded positions are more than an element size when the thickness is perturbed $\pm 50 \mathrm{~m}$. Therefore, for a wider selection of parameters, future work should either use higher order models or adaptive grid refinements.

\section{Results and discussion}

We start by applying cyclical perturbations on $C_{\mathrm{b}}, B, \dot{a}$, and $\dot{b}$ annually. The results 15 show that although the forcing function in Eq. (5) is symmetric around the reference value of each parameter, the GL migration need not be. Table 2 summarizes the deviations from the reference values of GL position and volume above flotation, as well as the oscillations around the reference values. The reference values are compared to the yearly-averaged values under cyclical forcing. The magnitude of deviations from the reference configurations depend both on the parameter and the amplitude of the perturbation applied.

When basal friction, $C_{\mathrm{b}}$ experiences $\pm 10 \%$ perturbation on annual timescale, the yearly-averaged GL position retreats over $0.4 \mathrm{~km}$ for downsloping geometry, and $1.0 \mathrm{~km}$ for the upsloping geometry. On the other hand, when ice hardness, $B$, is perturbed $\pm 0.15 \%$ on an annual timescale, the average GL retreat from the reference position is negligible (in the order of $10^{-3} \mathrm{~km}$ for both downsloping and upsloping geometries). The deviations from the reference configuration are also negligible when sub-shelf melting,

\section{A sensitivity study of fast outlet glaciers \\ E. Aykutlug and \\ T. K. Dupont}

Title Page



Full Screen / Esc

Printer-friendly Version

Interactive Discussion 
$\dot{b}$, or net accumulation rate, $\dot{a}$, experience annual perturbations. The perturbations on $\dot{a}$ are similar to the ones in $\dot{b}$, therefore from this point on, we will only focus on the results from $\dot{b}$.

The deviations for both $B$, and $\dot{b}$ lead to negligible perturbations, but for different 5 reasons. The perturbations on $\dot{b}$ did not lead to a significant bias from the reference configuration even though the perturbations were large, $\pm 50 \%$. This implies that even though the changes in sub-shelf melting has an important effect (e.g., Dutrieux et al., 2014; Rignot et al., 2010), the modeled dynamics are not sensitive to fast oscillations around the mean value of this parameter. On the other hand, the perturbations on ice 10 hardness, $B$, did not lead to a significant bias mainly because the amplitude of the perturbations were small. If ice hardness were to experience a percent perturbation similar in size to that of basal friction, the bias would also be of similar extent, but such large perturbations on $B$ would first need justification. In this paper, we only consider changes in $B$ due to atmospheric temperature changes. Including other physical pro15 cesses, e.g. damage (Borstad et al., 2013), could change this amount of perturbation on $B$.

Ice sheets are likely to experience different external forcings simultaneously, therefore we next consider applying two perturbations in combination with various phase lags (Fig. 2b). We apply eight different perturbations with phase lag of $\pi / 4^{\circ}$, ranging 20 from 0 to $2 \pi$, between $C_{\mathrm{b}}$ and other parameters. We only report the two cases that give the lower and upper limits of GL bias as shown in Table 2. When $\pm 0.15 \%$ perturbation on $B$ is applied in combination with the $\pm 10 \%$ perturbation on $C_{\mathrm{b}}$, the average GL retreat is still the same, over $0.4 \mathrm{~km}$, for the downsloping geometry. On the other hand, for the upsloping geometry, when two perturbations are applied together, the average GL retreat can change from 1.04 to $1.02 \mathrm{~km}$ or to $1.05 \mathrm{~km}$ depending on the phase lag. Even though these changes are quite small, the effect of applying two perturbations $\left(C_{\mathrm{b}}\right.$ and $\left.B\right)$ in combination is more than the linear sum of the individual effects (e.g., Parizek et al., 2013). Similarly, we applied perturbations on $\dot{b}$ with phase lags of $\pi / 4$, and report the values that give upper and lower limits in Table 2.

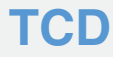

9, 223-250, 2015
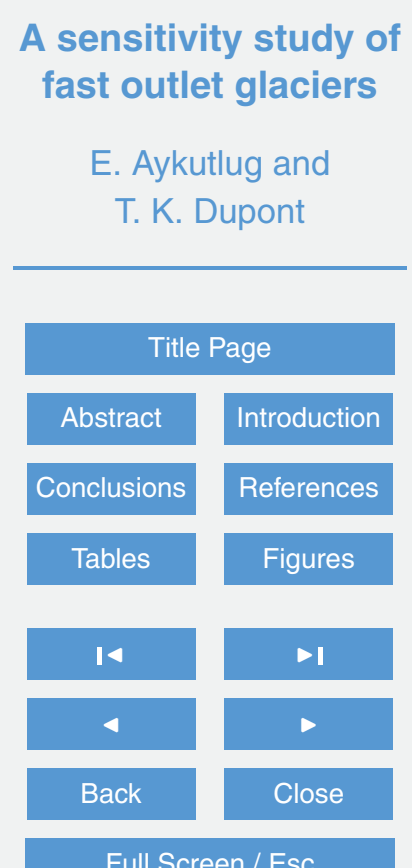

Full Screen / Esc

Printer-friendly Version

Interactive Discussion 
The volume-above flotation (VAF) is closely related to the GL position, but the changes in VAF directly reflect an outlet system's contribution to sea-level change. The changes in VAF under cyclical forcings are similar to the ones for GL. In Table 2 we compare the yearly-averaged VAF under cyclical forcing to the reference values.

5 Similar to the changes in GL position, the net amount of reduction in VAF depends on the parameter and the perturbation applied. The nonlinearities in ice dynamics also lead to nonlinear changes in VAF when the perturbations are applied in combination, as shown in Table 2.

Table 3 summarizes the results when the perturbations are applied on decadal 10 timescale. While the results are qualitatively similar to those of annual experiments, there are two main differences. First, the oscillations in decadal experiments are larger because the perturbations are applied for 5 years above and below the reference values, instead of 0.5 year. Second, the average amount of GL retreat and change in VAF from the reference configuration is smaller compared to the annual results. The velocity 15 changes over one period at the ice front also shows smaller variation. These results motivate that when considering perturbations not only the amplitude of the oscillations, but also the timescale they are applied can play a role.

\section{Sensitivity analysis of ice streams with different lengths and initial volume above flotation}

20 In the previous section, we have seen that only the cyclical perturbations on basal friction coefficient lead to a significant bias from the reference configurations. Therefore, in this section we will only focus on these perturbations. We investigate how the sensitivity to a cyclical perturbation changes as an ice stream becomes closer to flotation, and the perturbations are applied on longer ice streams. The values of the parameters used able to converge to the same GL position with an accuracy of $\pm 10^{-3} \mathrm{~km}$ when a $\pm 50 \mathrm{~m}$ perturbation was applied to the ice thickness and then subsequently removed.

\section{A sensitivity study of fast outlet glaciers \\ E. Aykutlug and \\ T. K. Dupont}

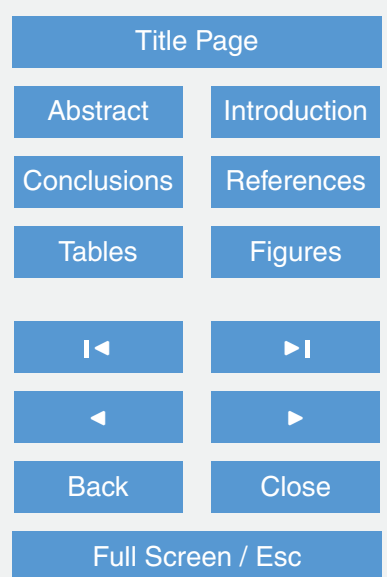

Printer-friendly Version

Interactive Discussion 
First, we consider whether ice streams of different lengths are affected similarly when basal friction coefficient, $C_{\mathrm{b}}$ experiences cyclical perturbation. We consider three different ice stream lengths, $L=150,175,200 \mathrm{~km}$. We start by selecting an influx value for each $L$, such that the grounded part of the ice stream is approximately $100 \mathrm{~km}$. 5 Therefore, the area that are affected by the the cyclical perturbations are approximately the same. Analyzing the deviations of the average GL positions, and percent change in VAF, Fig. 5, show that, for longer ice streams, the cyclical effects are more pronounced. For both downsloping and upsloping geometries the average GL retreat and the decrease in VAF increases with $L$.

10 For downsloping geometry, the average $\mathrm{GL}$ retreat does not change significantly for each case, where $L$ is $150 \mathrm{~km}, 175$ or $200 \mathrm{~km}$. On the other hand, for the upsloping geometry, the average GL retreat increases to 1.9 and $3.4 \mathrm{~km}$ when $L$ is 175 and $200 \mathrm{~km}$ respectively, which shows greater sensitivity for upsloping beds.

Next, we examine how an ice stream responds to cyclical perurbations of $C_{\mathrm{b}}$ as 15 it becomes closer to flotation. For each case, $L=150,175$ and $200 \mathrm{~km}$, we chose three different in-flux values, shown in Table 4, and apply cyclical perturbations starting from the corresponding reference configurations. Figure $6 a$ shows that for each $L$, the effects of cyclical perturbations are more pronounced for smaller in-flux values, i.e., for ice streams that are closer to flotation. In each case, the change in GL and VAF are measured relative to the initial values of the corresponding reference configuration. For all three different lengths of ice streams, as the in-flux values decrease, both the relative GL retreats and the relative decrease in VAF increases. Similar to the previous results, upsloping geometry shows higher sensitivity.

Finally, to briefly investigate how the results scale with the size of perturbations on 25
TCD

9, 223-250, 2015

A sensitivity study of fast outlet glaciers

E. Aykutlug and

T. K. Dupont



Full Screen / Esc

Printer-friendly Version

Interactive Discussion changes in the average VAF retreat for these test cases. 


\section{Conclusions}

This paper analyzes the sensitivity of outlet glaciers to annual and decadal variations of select parameters. We investigate whether there would be a bias in the ice dynamics, despite the forcing function being symmetric around the reference values. Using 5 a heuristic finite-element model, our results qualitatively show that these fast variations can have a non-negligible effect on ice dynamics under certain conditions. On shorter timescales GL dynamics may exhibit asymmetric response, similar to the long (orbital) timescale behavior shown by Parizek et al. (2010)

Consistent with previous studies, our results indicate that including variations in basal conditions can lead to a difference in modeling the behavior of outlet glaciers and ice streams. We also show that the effects are more pronounced for regions with upsloping bedrock geometries compared to the downsloping beds. Finally, the results also indicate that such short-timescale effects become more pronounced as ice streams become closer to flotation.

Future work should consider parameterizing such short timescale variations, and include a broader range of parameters, such as spatial variations (e.g., Enderlin et al., 2013b), higher oceanic forcings (e.g, Walker et al., 2008; Rignot et al., 2010; Vieli and Nick, 2011; Walsh et al., 2012), or changes in ice-front positions (e.g., Vieli and Nick, 2011; Podrasky et al., 2012; Joughin et al., 2012; Nick et al., 2013), which have been shown to have prominent effects on ice dynamics.

Acknowledgements. We greatly appreciate the support from NSF award ANT0809106, and NASA awards NNX08AQ82G and NNX09AW02G. We would like to thank Byron R. Parizek for his help with the manuscript and his comments which lead to improvements of this work. We also appreciate discussions with Ryan T. Walker, D. Seneca Lindsey, and the members of the 25 Cryosphere group at UC Irvine.
A sensitivity study of fast outlet glaciers

E. Aykutlug and

T. K. Dupont

Title Page



Full Screen / Esc

Printer-friendly Version

Interactive Discussion 


\section{References}

Alley, R. B., Anandakrishnan, S., Dupont, T. K., Parizek, B. R., and Pollard, D.: Effect of sedimentation on ice-sheet grounding-line stability, Science, 315, 1838-1841, doi:10.1126/science.1138396, 2007. 226

5 Amundson, J. M., Fahnestock, M., Truffer, M., Brown, J., Lúthi, M. P., and Motyka, R. J.: Ice melange dynamics and implications for terminus stability, Jakobshavn Isbrae, Greenland, J. Geophys. Res.-Earth, 115, F01005, doi:10.1029/2009JF001405, 2010. 224

Bamber, J. L., Vaughan, D. G., and Joughin, I.: Widespread complex flow in the interior of the Antarctic ice sheet, Science, 287, 1248-1250, doi:10.1126/science.287.5456.1248, 2000.

$10 \quad 224$

Borstad, C. P., Rignot, E., Mouginot, J., and Schodlok, M. P.: Creep deformation and buttressing capacity of damaged ice shelves: theory and application to Larsen $C$ ice shelf, The Cryosphere, 7, 1931-1947, doi:10.5194/tc-7-1931-2013, 2013. 232

Christianson, K., Parizek, B. R., Alley, R. B., Horgan, H. J., Jacobel, R. W., Anandakrishnan, S., 15 Kiesling, B. A., Craig, B. D., and Muto, A.: Ice sheet grounding zone stabilization due to till compaction, Geophys. Res. Lett., 40, 5406-5411, doi:10.1002/2013GL057447, 2013. 226

Comiso, J. C.: Variability and trends in Antarctic surface temperatures from in situ and satellite infrared measurements, J. Climate, 13, 1674-1696, doi:10.1175/15200442(2000)013<1674:VATIAS>2.0.CO;2, 2000. 230

Cuffey, K. M. and Paterson, W. S. B.: The Physics of Glaciers, 4th edn., Academic Press, USA, 2010. 227, 230

Docquier, D., Perichon, L., and Pattyn, F.: Representing grounding line dynamics in numerical ice sheet models: recent advances and outlook, Surv. Geophys., 32, 417-435, doi:10.1007/s10712-011-9133-3, 2011. 228

25 Dupont, T. K.: Abrupt changes in ice shelves and ice streams: model studies, Ph. D. thesis, Pennsylvania State University, PA, 2004. 226, 227

Dupont, T. K. and Alley, R. B.: Assessment of the importance of ice-shelf buttressing to icesheet flow, Geophys. Res. Lett., 32, L04503, doi:10.1029/2004GL022024, 2005. 226

Durand, G., Gagliardini, O., Zwinger, T., Meur, E. L., and Hindmarsh, R.: Full-Stokes modeling of marine ice-sheets: influence of the grid size, Ann. Glaciol., 50, 109-114, 2009. 228

9, 223-250, 2015

A sensitivity study of fast outlet glaciers

E. Aykutlug and

T. K. Dupont

Title Page

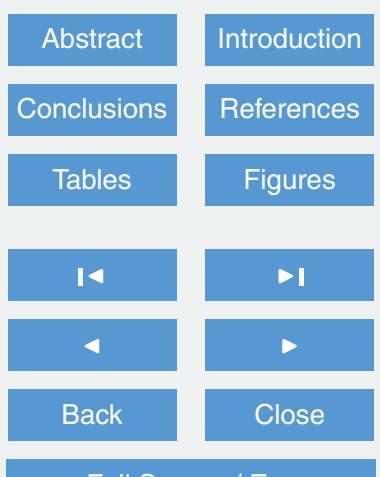

Full Screen / Esc

Printer-friendly Version

Interactive Discussion 
Dutrieux, P., Rydt, J. D., Jenkins, A., Holland, P. R., Ha, H. K., Lee, S. H., Steig, E. J., Ding, Q., Abrahamsen, E. P., and Schroder, M.: Strong sensitivity of Pine Island ice-shelf melting to climatic variability, Science, 343, 174-178, doi:10.1126/science.1244341, 2014. 231, 232

Enderlin, E. M., Howat, I. M., and Vieli, A.: High sensitivity of tidewater outlet glacier dynamics to shape, The Cryosphere, 7, 1007-1015, doi:10.5194/tc-7-1007-2013, 2013a. 225

Enderlin, E. M., Howat, I. M., and Vieli, A.: The sensitivity of flowline models of tidewater glaciers to parameter uncertainty, The Cryosphere, 7, 1579-1590, doi:10.5194/tc-7-15792013, 2013b. 225, 229, 235

Enderlin, E. M., Howat, I. M., Jeong, S., Noh, M. J., van Angelen, J. H., and van den Broeke, M. R.: An improved mass budget for the Greenland ice sheet, Geophys. Res. Lett., 41, 866-872, doi:10.1002/2013GL059010, 2014. 224

Favier, L., Gagliardini, O., Durand, G., and Zwinger, T.: A three-dimensional full Stokes model of the grounding line dynamics: effect of a pinning point beneath the ice shelf, The Cryosphere, 6, 101-112, doi:10.5194/tc-6-101-2012, 2012. 226

Gladstone, R., Schäfer, M., Zwinger, T., Gong, Y., Strozzi, T., Mottram, R., Boberg, F., and Moore, J. C.: Importance of basal processes in simulations of a surging Svalbard outlet glacier, The Cryosphere, 8, 1393-1405, doi:10.5194/tc-8-1393-2014, 2014. 225

Gladstone, R. M., Payne, A. J., and Cornford, S. L.: Parameterising the grounding line in flowline ice sheet models, The Cryosphere, 4, 605-619, doi:10.5194/tc-4-605-2010, 2010. 228

20

Goldberg, D., Holland, D. M., and Schoof, C.: Grounding line movement and ice shelf buttressing in marine ice sheets, J. Geophys. Res., 114, F04026, doi:10.1029/2008JF001227, 2009. 226, 228

Gudmundsson, G. H.: Ice-shelf buttressing and the stability of marine ice sheets, The Cryosphere, 7, 647-655, doi:10.5194/tc-7-647-2013, 2013. 226

Gudmundsson, G. H., Krug, J., Durand, G., Favier, L., and Gagliardini, O.: The stability of grounding lines on retrograde slopes, The Cryosphere, 6, 1497-1505, doi:10.5194/tc-61497-2012, 2012. 226

Habermann, M., Truffer, M., and Maxwell, D.: Changing basal conditions during the speed-up of Jakobshavn Isbræ, Greenland, The Cryosphere, 7, 1679-1692, doi:10.5194/tc-7-1679-2013, $30 \quad$ 2013. 225

Hall, D. K., Comiso, J. C., DiGirolamo, N. E., Shuman, C. A., Box, J. E., and Koenig, L.: Variability in the surface temperature and melt extent of the Greenland ice sheet from MODIS, Geophys. Res. Lett., 40, 2114-2120, doi:10.1002/grl.50240, 2013. 230
TCD

9, 223-250, 2015

A sensitivity study of fast outlet glaciers

E. Aykutlug and

T. K. Dupont

Title Page

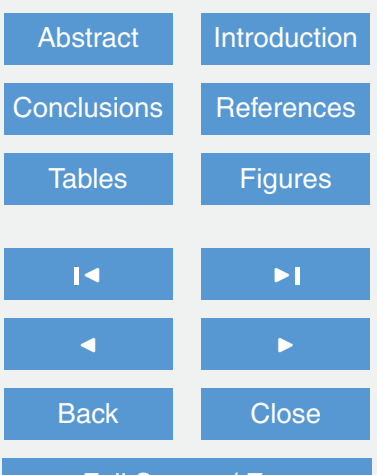

Full Screen / Esc

Printer-friendly Version

Interactive Discussion 
Hindmarsh, R. C. A.: Stability of ice rises and uncoupled marine ice sheets, Ann. Glaciol., 23, 94-104, 1996. 225

Hoffman, M. J., Catania, G. A., Neumann, T. A., Andrews, L. C., and Rumrill, J. A.: Links between acceleration, melting, and supraglacial lake drainage of the western Greenland Ice

$5 \quad$ Sheet, J. Geophys. Res., 116, F04035, doi:10.1029/2010JF001934, 2011. 225, 230

Holland, D. M., Thomas, R. H., de Young, B., Ribergaard, M. H., and Lyberth, B.: Acceleration of Jakobshavn Isbrae triggered by warm subsurface ocean waters, Nat. Geosci., 1, 659-664, doi:10.1038/ngeo316, 2008. 224

Howat, I. M., Joughin, I., Fahnestock, M., Smith, B. E., and Scambos, T. A.: Synchronous retreat and acceleration of southeast Greenland outlet glaciers 2000-06: ice dynamics and coupling to climate, J. Glaciol., 54, 646-660, doi:10.3189/002214308786570908, 2008. 224, 225

Howat, I. M., Box, J. E., Ahn, Y., Herrington, A., and McFadden, E. M.: Seasonal variability in the dynamics of marine-terminating outlet glaciers of Greenland, J. Glaciol., 56, 601-613, 2010. 224, 225

Joughin, I., Smith, B. E., Howat, I., Floricioiu, D., Alley, R. B., Truffer, M., and Fahnestock, M.: Seasonal to decadal scale variations in the surface velocity of Jakobshavn Isbrae, Greenland: observation and model-based analysis, J. Geophys. Res., 117, F02030, doi:10.1029/2011JF002110, 2012. 224, 225, 228, 229, 230, 235

Joughin, I., Smith, B. E., Shean, D. E., and Floricioiu, D.: Brief Communication: Further summer speedup of Jakobshavn Isbræ, The Cryosphere, 8, 209-214, doi:10.5194/tc-8-209-2014, 2014. 224, 230

MacAyeal, D. R.: Large-scale ice flow over a viscous basal sediment: theory and application to Ice Stream B, Antarctica, J. Geophys. Res.-Sol. Ea., 94, 4071-4087, doi:10.1029/JB094iB04p04071, 1989. 227

Moon, T., Joughin, I., Smith, B., and Howat, I.: Ice flow in Greenland for the International Polar Year 2008-2009, Science, 336, 576-578, doi:10.1126/science.1219985, 2012. 224

Morland, L. W.: Unconfined ice-shelf flow, in: Dynamics of the West Antarctic Ice Sheet, edited by: van der Veen, C. J. and Oerlemans, J., D. Reidel, Boston, 1987. 227

Morlighem, M., Rignot, E., Mouginot, J., Seroussi, H., and Larour, E.: Deeply incised 30 submarine glacial valleys beneath the Greenland Ice Sheet, Nat. Geosci., 7, 418-422, doi:10.1038/ngeo2167, 2014. 226

9, 223-250, 2015

A sensitivity study of fast outlet glaciers

E. Aykutlug and

T. K. Dupont

Title Page

Abstract

Introduction

Conclusions References

Tables

Figures

14

$>1$

4

Back

$>$

Close

Full Screen / Esc

Printer-friendly Version

Interactive Discussion 
Nick, F. M., Vieli, A., Andersen, M. L., Joughin, I., Payne, A., Edwards, T. L., Pattyn, F., and van de Wal, R. S. W.: Future sea-level rise from Greenland's main outlet glaciers in a warming climate, Nature, 497, 235-238, doi:10.1038/nature12068, 2013. 225, 235

Parizek, B., Christianson, K., Anandakrishnan, S., Alley, R. B., Walker, R. T., Edwards, R. A., Wolfe, D., Bertini, G. T., Rinehart, S. K., Bindschadler, R. A., and Nowicki, S. M. J.: Dynamic (in)stability of Thwaites Glacier, West Antarctica, J. Geophys. Res.-Earth, 118, 638-655, doi:10.1002/jgrf.20044, 2013. 232

Parizek, B. R., Alley, R. B., Dupont, T. K., Walker, R. T., and Anandakrishnan, S.: Effect of orbital-scale climate cycling and meltwater drainage on ice sheet grounding line migration, J. Geophys. Res.-Earth, 115, F01011, doi:10.1029/2009JF001325, 2010. 226, 235

Pattyn, F., Schoof, C., Perichon, L., Hindmarsh, R. C. A., Bueler, E., de Fleurian, B., Durand, G., Gagliardini, O., Gladstone, R., Goldberg, D., Gudmundsson, G. H., Huybrechts, P., Lee, V., Nick, F. M., Payne, A. J., Pollard, D., Rybak, O., Saito, F., and Vieli, A.: Results of the Marine Ice Sheet Model Intercomparison Project, MISMIP, The Cryosphere, 6, 573-588, doi:10.5194/tc-6-573-2012, 2012. 226, 227, 228

Pattyn, F., Perichon, L., Durand, G., Favier, L., Gagliardini, O., Hindmarsh, R. C. A., Zwinger, T., Albrecht, T., Cornford, S., Docquier, D., Furst, J., Goldberg, D., Gudmundsson, G. H., Humbert, A., Hutten, M., Huybrechts, P., Jouvet, G., Kleiner, T., Larour, E., Martin, D., Morlighem, M., Payne, A. J., Pollard, D., Ruckamp, M., Rybak, O., Seroussi, H., Thoma, M., and Wilkens, N.: Grounding-line migration in plan-view marine ice-sheet models: results of the ice2sea MISMIP3d intercomparison, J. Glaciol., 59, 410-422, doi:10.3189/2013JoG12J129, 2013. 226, 228

Podrasky, D., Truffer, M., Fahnestock, M., Amundson, J. M., Cassotto, R., and Joughin, I.: Outlet glacier response to forcing over hourly to interannual timescales, Jakobshavn Isbrae, Greenland, J. Glaciol., 58, 1212-1226, doi:10.3189/2012JoG12J065, 2012. 224, 228, 229, 235

Rignot, E., Koppes, M., and Velicogna, I.: Rapid submarine melting of the calving faces of West Greenland glaciers, Nat. Geosci., 3, 187-191, doi:10.1038/ngeo765, 2010. 231, 232, 235

Rignot, E., Mouginot, J., and Scheuchl, B.: Ice flow of the Antarctic ice sheet, Science, 333, 1427-1430, doi:10.1126/science.1208336, 2011. 224

30 Rignot, E., Jacobs, S., Mouginot, J., and Scheuchl, B.: Ice shelf melting around Antarctica, Science, 341, 266-270, doi:10.1126/science.1235798, 2013. 231

Schoof, C.: Ice sheet grounding line dynamics: Steady states, stability, and hysteresis, J. Geophys. Res.-Earth, 112, F03S28, doi:10.1029/2006JF000664, 2007. 225, 226
A sensitivity study of fast outlet glaciers

E. Aykutlug and

T. K. Dupont

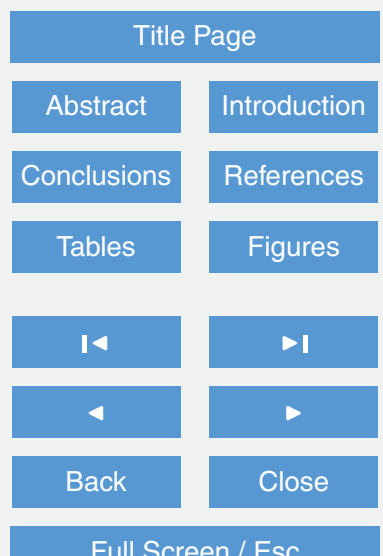

Full Screen / Esc

Printer-friendly Version

Interactive Discussion 
Schoof, C.: Ice-sheet acceleration driven by melt supply variability, Nature, 468, 803-806, doi:10.1038/nature09618, 2010. 225

Schoof, C.: Marine Ice Sheet Stability, J. Fluid Mech., 698, 62-72, doi:10.1017/jfm.2012.43, 2012. 225

5 Seroussi, H., Morlighem, M., Larour, E., Rignot, E., and Khazendar, A.: Hydrostatic grounding line parameterization in ice sheet models, The Cryosphere, 8, 2075-2087, doi:10.5194/tc-82075-2014, 2014. 228

Vieli, A. and Nick, F. M.: Understanding and modeling rapid dynamic changes of tidewater outlet glaciers: issues and implications, Surv. Geophys., 32, 437-458, doi:10.1007/s10712011-9132-4, 2011. 225, 228, 229, 235

Vieli, A. and Payne, A. J.: Assessing the ability of numerical ice sheet models to simulate grounding line migration, J. Geophys. Res.-Earth, 110, F01003, doi:10.1029/2004JF000202, 2005. 228

Walker, R. T., Dupont, T. K., Parizek, B. R., and Alley, R. B.: Effects of basal-melting distribution on the retreat of ice-shelf grounding lines, Geophys. Res. Lett., 35, L17503, doi:10.1029/2008GL034947, 2008. 226, 231, 235

Walsh, K. M., Howat, I. M., Ahn, Y., and Enderlin, E. M.: Changes in the marine-terminating glaciers of central east Greenland, 2000-2010, The Cryosphere, 6, 211-220, doi:10.5194/tc6-211-2012, 2012. 235

Weertman, J.: Stability of the junction of an ice-sheet and an ice-shelf, J. Glaciol., 13, 3-11, 1974. 225

Wexler, H.: Seasonal and other temperature changes in the Antarctic atmosphere, Q. J. Roy. Meteor. Soc., 85, 196-208, doi:10.1002/qj.49708536503, 1959. 230

Zwally, H. J., Abdalati, W., Herring, T., Larson, K., Saba, J., and Steffan, K.: Surface melt induced acceleration of greenland ice-sheet flow, Science, 297, 218-222, doi:10.1126/science.1072708, 2002. 224

\section{TCD}

9, 223-250, 2015

A sensitivity study of

fast outlet glaciers

E. Aykutlug and

T. K. Dupont

Title Page

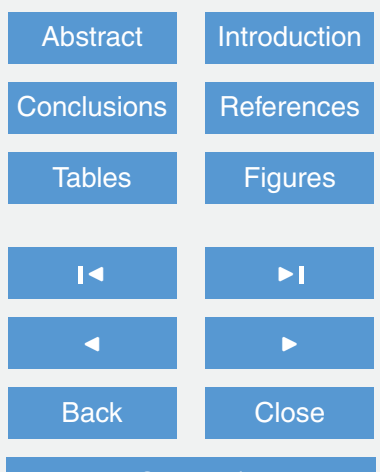

Full Screen / Esc

Printer-friendly Version

Interactive Discussion 
Table 1. Explanation and numerical values of nominal parameters for downsloping and upsloping bedrock geometries.

\begin{tabular}{|c|c|c|c|}
\hline Parameter & Description & Value & Units \\
\hline$\rho_{i}$ & ice density & 917 & $\mathrm{kgm}^{-3}$ \\
\hline$\rho_{\mathrm{w}}$ & sea water density & 1028 & $\mathrm{kgm}^{-3}$ \\
\hline$g$ & gravitational acceleration & 9.81 & $\mathrm{~ms}^{-2}$ \\
\hline$L$ & domain length & 150 & km \\
\hline$W$ & domain half width & 20 & $\mathrm{~km}$ \\
\hline$n$ & Glen's flow law exponent & 3 & \\
\hline$m$ & basal friction exponent & 3 & \\
\hline$A$ & nominal ice softness & $3.3 \times 10^{-25}$ & $\mathrm{~Pa}^{-3} \mathrm{~s}^{-1}$ \\
\hline$C_{\mathrm{s}}$ & nominal lateral drag coefficient $\left\{\begin{array}{l}\text { downsloping bed } \\
\text { upsloping bed }\end{array}\right.$ & $\begin{array}{l}1.65 \times 10^{6} \\
2.60 \times 10^{6}\end{array}$ & $\mathrm{Pam}^{-\frac{1}{3}} \mathrm{~s}^{\frac{1}{3}}$ \\
\hline$C_{\mathrm{b}}$ & nominal basal drag coefficient $\left\{\begin{array}{l}\text { downsloping bed } \\
\text { upsloping bed }\end{array}\right.$ & $\begin{array}{l}1.40 \times 10^{6} \\
1.50 \times 10^{6}\end{array}$ & $\mathrm{Pam}^{-\frac{1}{3}} \mathrm{~S}^{\frac{1}{3}}$ \\
\hline$\dot{a}$ & nominal net accumulation rate $\left\{\begin{array}{l}\text { downsloping bed } \\
\text { upsloping bed }\end{array}\right.$ & $\begin{array}{l}0.20 \\
0.02\end{array}$ & $\mathrm{ma}^{-1}$ \\
\hline$\dot{b}$ & nominal sub-shelf melt rate $\left\{\begin{array}{l}\text { downsloping bed } \\
\text { upsloping bed }\end{array}\right.$ & $\begin{array}{l}-1.0 \\
-1.0\end{array}$ & $\mathrm{ma}^{-1}$ \\
\hline$q_{0}$ & in flux rate $\left\{\begin{array}{l}\text { downsloping bed } \\
\text { upsloping bed }\end{array}\right.$ & $\begin{array}{l}5.5 \times 10^{-2} \\
7.1 \times 10^{-2}\end{array}$ & $m^{2} a^{-1}$ \\
\hline$Z_{\text {bed }}$ & bedrock elevation $\left\{\begin{array}{l}\text { downsloping bed } \\
\text { upsloping bed }\end{array}\right.$ & $\begin{array}{r}-400-\frac{3 x}{1000} \\
-1200+\frac{3 x}{1000}\end{array}$ & $\mathrm{~m}$ \\
\hline
\end{tabular}

A sensitivity study of fast outlet glaciers

E. Aykutlug and

T. K. Dupont

\section{Title Page}

Abstract

Introduction

Conclusions

References

Tables

Figures

$1<$

4

Back

Full Screen / Esc

Printer-friendly Version

Interactive Discussion 
Table 2. Deviations from the reference steady-state grounding-line position after 3000 years, when a parameter experiences an annual perturbation. The cyclical values, $\Delta \overline{\mathrm{GL}}_{x}$ and $\Delta \overline{\mathrm{VAF}}$, are yearly averaged.

\begin{tabular}{cccccccc}
\hline Parameter & $\begin{array}{c}\text { Average } \\
\text { Perturbation }\end{array}$ & \multicolumn{2}{c}{$\Delta \overline{\mathrm{GL}}_{x}[\mathrm{~km}]$} & \multicolumn{2}{c}{$\begin{array}{c}\text { Seasonal G.L. position } \\
\text { oscillations [km] }\end{array}$} & \multicolumn{2}{c}{$\Delta \overline{\mathrm{VAF}} \%$} \\
& & down. & up. & down. & up. & down. & up. \\
\hline only $C_{\mathrm{b}}$ & $\pm 10 \%$ & -0.41 & -1.04 & 0.22 & 0.50 & -2.79 & -4.31 \\
only $B$ & $\pm 0.15 \%$ & -0.00 & -0.00 & 0.00 & 0.00 & -0.0 & -0.0 \\
only $\dot{a}$ & $\pm 50 \%$ & 0.00 & -0.00 & 0.01 & 0.00 & -0.0 & -0.0 \\
only $\dot{b}$ & $\pm 50 \%$ & -0.00 & -0.00 & 0.00 & 0.01 & -0.0 & -0.0 \\
$C_{\mathrm{b}} \& B$ & $\begin{array}{c}\text { phase } \\
\text { lag }=0\end{array}$ & -0.41 & -1.02 & 0.22 & 0.50 & -2.79 & -4.28 \\
$C_{\mathrm{b}} \& B$ & $\begin{array}{c}\text { phase } \\
\text { lag }=\pi\end{array}$ & -0.42 & -1.05 & 0.23 & 0.51 & -2.79 & -4.33 \\
$C_{\mathrm{b}} \& \dot{b}$ & $\begin{array}{c}\text { phase } \\
\text { lag }=3 \pi / 4\end{array}$ & -0.41 & -1.02 & 0.22 & 0.50 & -2.78 & -4.28 \\
$C_{\mathrm{b}} \& \dot{b}$ & $\begin{array}{c}\text { phase } \\
\text { lag }=7 \pi / 4\end{array}$ & -0.41 & -1.05 & 0.22 & 0.51 & -2.79 & -4.34 \\
& & & & & & \\
\hline
\end{tabular}

9, 223-250, 2015

A sensitivity study of fast outlet glaciers

E. Aykutlug and

T. K. Dupont

Title Page

Abstract

Introduction

Conclusions

References

Tables

Figures

14

4

Back

Close

Full Screen / Esc

Printer-friendly Version

Interactive Discussion 
Table 3. Deviations from the reference steady-state grounding-line position after 3000 years, when a parameter experiences a decadal perturbation. The cyclical values, $\Delta \overline{\mathrm{GL}}_{x}$ and $\Delta \overline{\mathrm{VAF}}$, are decadally averaged.

\begin{tabular}{ccrrrrrr}
\hline Parameter & $\begin{array}{c}\text { Average } \\
\text { Perturbation }\end{array}$ & \multicolumn{2}{c}{$\Delta \overline{\mathrm{GL}}_{x}[\mathrm{~km}]$} & \multicolumn{3}{c}{$\begin{array}{c}\text { Decadal G.L. position } \\
\text { oscillations [km] }\end{array}$} & \multicolumn{2}{c}{$\Delta \overline{\mathrm{VAF}} \%$} \\
& & down. & up. & down. & \multicolumn{1}{c}{ up. } & down. & up. \\
\hline only $C_{\mathrm{b}}$ & $\pm 10 \%$ & -0.40 & -0.77 & 1.89 & 3.84 & -2.63 & -3.18 \\
only $B$ & $\pm 0.4 \%$ & -0.00 & 0.00 & 0.06 & 0.10 & -0.00 & 0.01 \\
only $\dot{b}$ & $\pm 50 \%$ & -0.00 & 0.00 & 0.01 & 0.03 & -0.00 & 0.00 \\
only $\dot{a}$ & $\pm 50 \%$ & -0.00 & 0.00 & 0.06 & 0.01 & -0.00 & 0.00 \\
$C_{\mathrm{b}} \& B$ & $\begin{array}{c}\text { phase } \\
\text { lag }=2 \pi / 4\end{array}$ & -0.41 & -0.82 & 1.84 & 3.90 & -2.64 & -3.23 \\
$C_{\mathrm{b}} \& B$ & $\begin{array}{c}\text { phase } \\
\text { lag }=6 \pi / 4\end{array}$ & -0.39 & -0.73 & 1.94 & 3.81 & -2.63 & -3.10 \\
$C_{\mathrm{b}} \& \dot{b}$ & $\begin{array}{c}\text { phase } \\
\text { lag }=2 \pi / 4\end{array}$ & -0.40 & -0.75 & 1.91 & 3.89 & -2.63 & -3.11 \\
$C_{\mathrm{b}} \& \dot{b}$ & $\begin{array}{c}\text { phase } \\
\text { lag }=6 \pi / 4\end{array}$ & -0.40 & -0.79 & 1.88 & 3.82 & -2.64 & -3.18 \\
& & & & & & & \\
\hline
\end{tabular}

9, 223-250, 2015

A sensitivity study of fast outlet glaciers

E. Aykutlug and

T. K. Dupont

Title Page

Abstract

Introduction

Conclusions References

Tables

Figures

14

4

Back

Close

Printer-friendly Version

Interactive Discussion 
Table 4. Explanation and numerical values of nominal parameters for downsloping and upsloping bedrock geometries. The parameters, $\rho_{i}, \rho_{\mathrm{w}}, g, W, n, m, A, Z_{\text {bed }}, C_{\mathrm{b}}$, and $C_{\mathrm{s}}$ are the same as Table $1, \dot{a}$ and $\dot{b}$ are 0 in all the cases below.

\begin{tabular}{cccccccc}
\hline$q_{0}$ & \multirow{2}{*}{ Units } & \multicolumn{2}{c}{$L=150 \mathrm{~km}$} & \multicolumn{2}{c}{$L=175 \mathrm{~km}$} & \multicolumn{2}{c}{$L=200 \mathrm{~km}$} \\
& & down. & up. & down. & up. & down. & up. \\
\hline$q_{1}$ & $\mathrm{~m}^{2} \mathrm{yr}^{-1}$ & 0.055 & 0.060 & 0.035 & 0.0395 & 0.25 & 0.0246 \\
$q_{2}$ & $\mathrm{~m}^{2} \mathrm{yr}^{-1}$ & 0.060 & 0.065 & 0.040 & 0.0405 & 0.30 & 0.0256 \\
$q_{3}$ & $\mathrm{~m}^{2} \mathrm{yr}^{-1}$ & 0.065 & 0.070 & 0.045 & 0.0415 & 0.35 & 0.0266 \\
\hline
\end{tabular}

A sensitivity study of fast outlet glaciers

E. Aykutlug and

T. K. Dupont

\section{Title Page}

Abstract

Introduction

Conclusions

References

Tables

Figures

14

4

Back

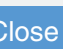

Full Screen / Esc

Printer-friendly Version

Interactive Discussion 

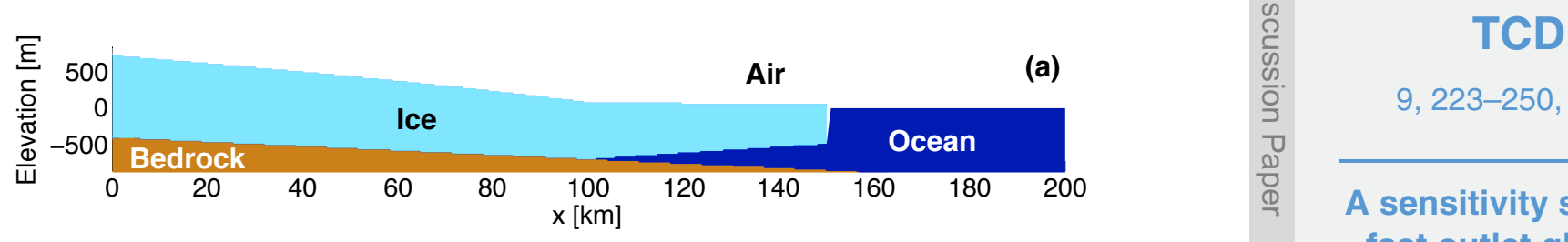

\section{9, 223-250, 2015}

A sensitivity study of fast outlet glaciers

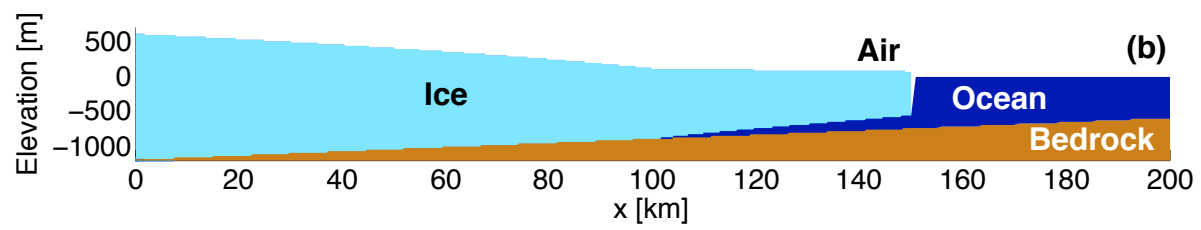

(b)
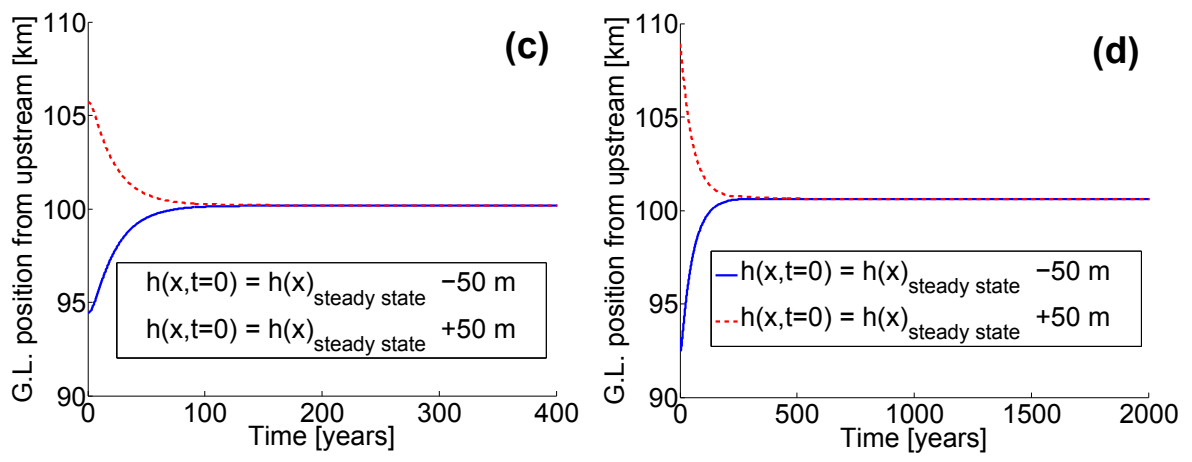

Figure 1. Steady-state ice thickness and geometry in (a) downsloping, and (b) upsloping bedrock geometry, when nominal (reference) values of parameters listed in Table 1 are used. The cyclical experiments are initialized with these steady states. Grounding-line position after the ice thickness is perturbed $\pm 50 \mathrm{~m}$ from the reference configuration, in (a) downsloping, (b) upsloping geometry. In each case, the grounding line converges back to the same position after perturbations are removed.

\section{E. Aykutlug and \\ T. K. Dupont}

\section{Title Page}

Abstract

Introduction

Conclusions

References

Tables

Figures

14

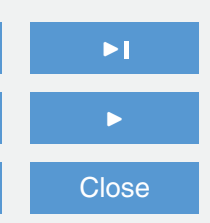

Back

Close

Full Screen / Esc

Printer-friendly Version

Interactive Discussion

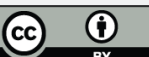



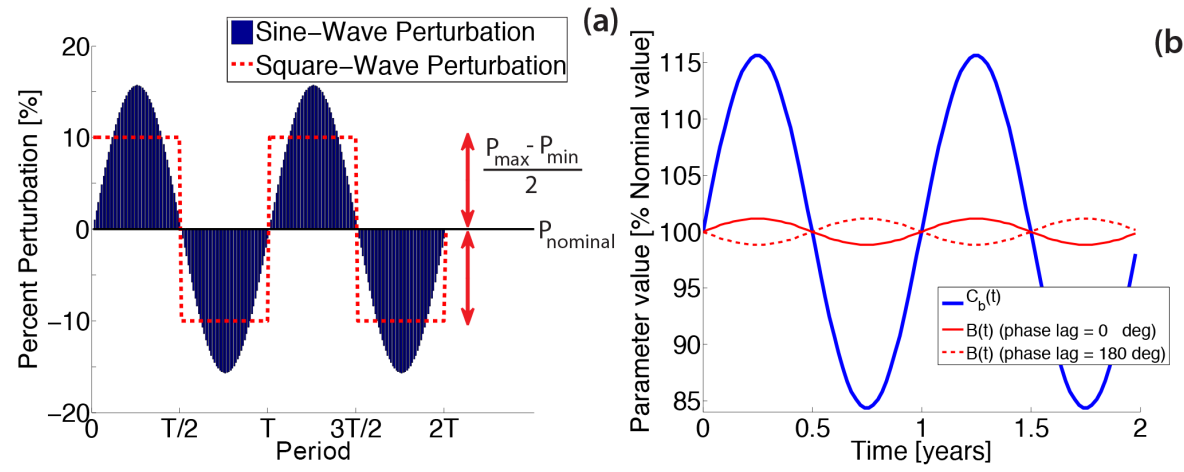

Figure 2. (a) The sinusoidal perturbation applied on a parameter $p$, and the square-wave function that has the same cumulative perturbation each half of the period ( $T=1$ or $T=10$ years). (b) Normalized periodic perturbations in $C_{\mathrm{b}}$ and $B$ applied with various phase lags applied in combined perturbations. In phase (phase lag $=0^{\circ}$ ) and out of phase (phase lag $=180^{\circ}$ ) perturbations are plotted in black solid and black dashed lines respectively.

\section{TCD}

9, 223-250, 2015

A sensitivity study of fast outlet glaciers

\section{E. Aykutlug and \\ T. K. Dupont}

\section{Title Page}

Abstract Introduction

Conclusions

14

4

Back

Close

Printer-friendly Version

Interactive Discussion 

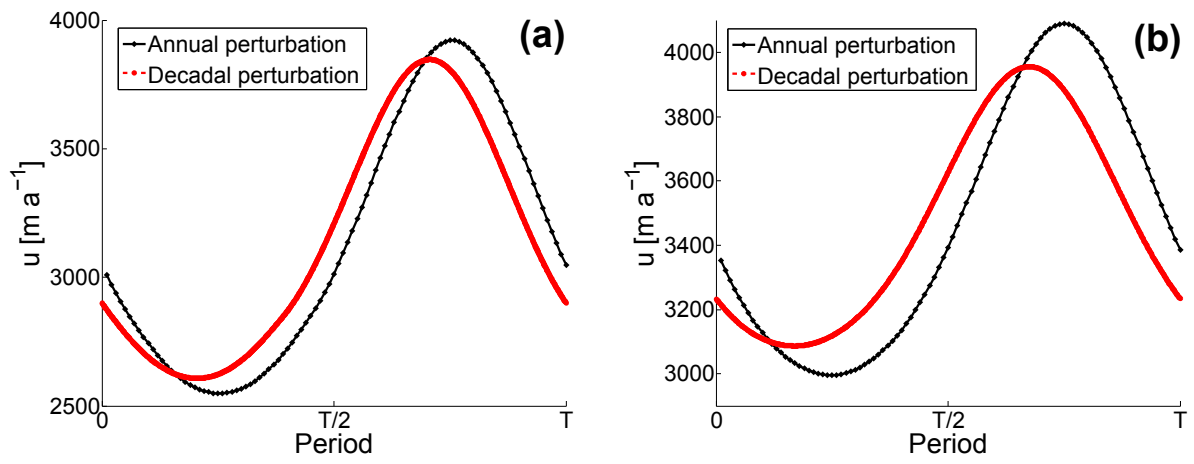

(b)

TCD

9, 223-250, 2015

A sensitivity study of fast outlet glaciers

E. Aykutlug and

T. K. Dupont

Title Page

Abstract

Introduction

Conclusions

References

Tables

Figures

Figure 3. Ice-front velocity variations during cyclical perturbations applied on basal friction coefficient. The time axis is scaled by the period of perturbations. $T$ represents 1 and 10 years for the annual and decadal perturbations respectively. The plots are shown for both (a) downsloping and (b) upsloping geometries. (a) The maximum to minimum velocity ratios are $56.6 \%$ and $48 \%$ for the downsloping geometry under annual and decadal perturbations respectvely. (b) Similarly for the upsloping geometry the change in velocity is $36 \%$ and $28 \%$ for annual and decadal perturbations respectively.

14

4

Back
>I

$\triangleright$

Close

Full Screen / Esc

Printer-friendly Version

Interactive Discussion 

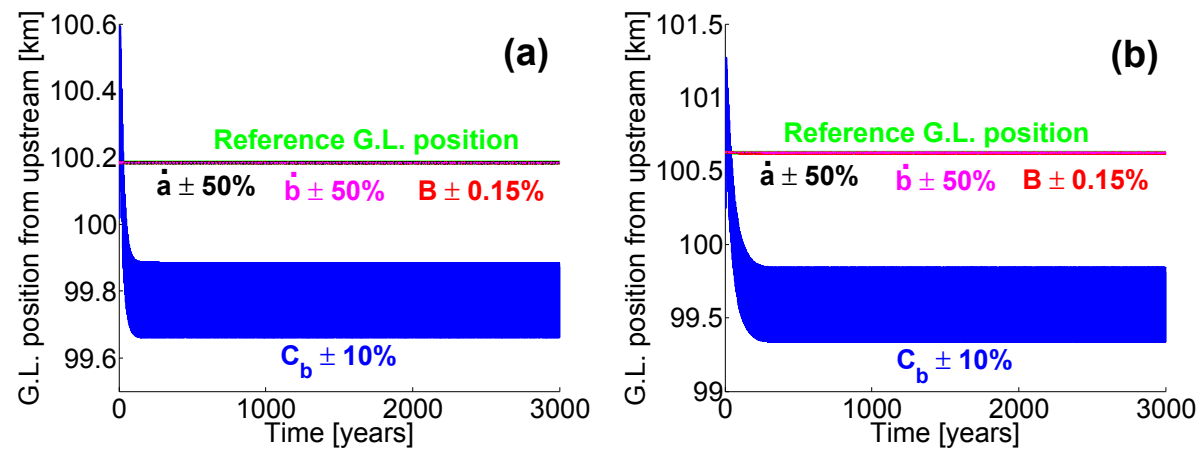

(b)

TCD

9, 223-250, 2015

A sensitivity study of fast outlet glaciers

E. Aykutlug and

T. K. Dupont

Title Page

Abstract

Introduction

Conclusions

References

Tables

Figures

Figure 4. Grounding-line positions with respect to time as basal friction coefficient, $C_{\mathrm{b}}$, ice hardness, $B$, net accumulation rate, $\dot{a}$, and sub-shelf melt rate, $\dot{b}$ experience annual perturbations for the (a) downsloping and (b) upsloping geometries. The GL positions corresponding to the reference steady-states are plotted in green in both cases.

14

4

Back
DI



Full Screen / Esc

Printer-friendly Version

Interactive Discussion 

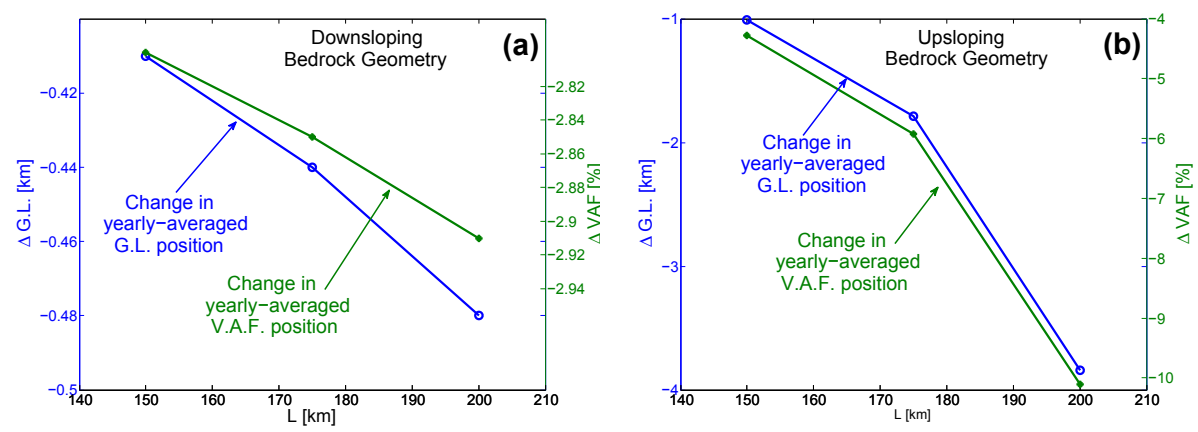

\section{TCD}

9, 223-250, 2015

A sensitivity study of fast outlet glaciers

E. Aykutlug and

T. K. Dupont

Title Page

Abstract

Introduction

Conclusions

References

Tables

Figures

Figure 5. Changes in yearly averaged GL positions and volume above flotations are plotted for (a) downsloping (b) upsloping bedrock geometries. For each case, a reference in-flux value is chosen such that the initial grounded area approximately covers $100 \mathrm{~km}$ of grounded ice. As the ice stream length increases, both the retreat in yearly averaged GL position, and the decrease in VAF increases.

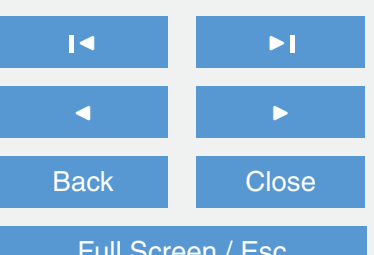

Full Screen / Esc

Printer-friendly Version

Interactive Discussion 

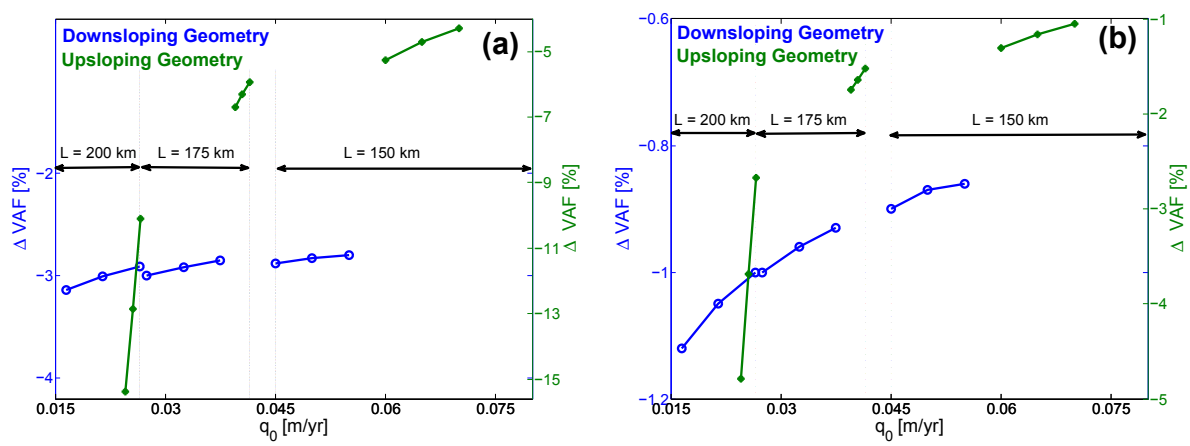

TCD

9, 223-250, 2015

A sensitivity study of fast outlet glaciers

E. Aykutlug and

T. K. Dupont

Title Page

Abstract

Introduction

Conclusions

References

Tables

Figures

Figure 6. Change in yearly averaged VAF are plotted for different influx values. The results are shown for both (a) $10 \%$ and (b) $5 \%$ annual perturbation in $C_{\mathrm{b}}$. For both the downsloping and the upsloping geometries, as the in-flux values are reduced, i.e., the ice-stream becomes closer to flotation, the relative decrease in VAF increases. The in-flux values that correspond to different ice stream lengths are separated by dashed lines and marked by the corresponding ice stream lengths.

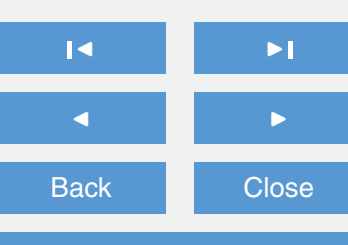

Full Screen / Esc

Printer-friendly Version

Interactive Discussion 